\title{
Evaluation of data input in a rabies testing request form for herbivores
}

\section{Avaliação da entrada de dados em um formulário de requisição de exame de raiva para herbívoros}

\author{
Victória Furtado Migliavacca' (1) (orcid.org/0000-0001-7699-3238) \\ Michelle Elias Peres ${ }^{1}$ (i) (orcid.org/0000-0001-7618-2523) \\ José Carlos Ferreira' ${ }^{1}$ (1) (orcid.org/0000-0002-4315-9359) \\ Júlio César de Almeida Rosa' (10) (orcid.org/0000-0003-0778-0102) \\ Alexandre de Carvalho Braga' (1) (orcid.org/0000-0003-4237-2761) \\ Laura Lopes de Almeida' (1) (orcid.org/0000-0002-6131-9221) \\ Giovana Dantas de Araujo' (1) (orcid.org/0000-0001-6530-1603) \\ Angélica Cavalheiro Bertagnolli2* (1) (orcid.org/0000-0002-4956-2085)
}

\begin{abstract}
Bovines and equines are the domestic animals with the highest incidence of rabies in Brazil. This study evaluated the data input in testing request forms for rabies in herbivores accompanying samples sent to a certified laboratory of rabies diagnosis in the state of Rio Grande do Sul, Brazil. Information was obtained systematically from all forms sent to the laboratory in 2013 and 2014 using a collection instrument that listed variables about the kind of form used, municipality of origin, description of the suspected animal, clinical signs, sample collection, and conservation procedure. The 11 most relevant variables (municipality of origin, geographic coordinates, species, gender, breed, age, herd size, clinical signs, persistence of clinical signs, biological material, and sample conservation) were assessed for the quality of the data entered, and percentage data input was calculated per form. In total, 603 forms were sent to the laboratory. The most used form was the FORM SN, (82.0\%, 497/603). "Excellent" and "good" data inputs were observed only for one variable describing the location of suspected rabies cases or outbreaks and animals (species, gender, biological material). Quality of data input of variables describing geographic coordinates, age, breed, herd size, clinical signs, persistence of signs, and sample conservation method varied between "average" and "poor". The data input in testing request forms for herbivores are not dully supplied in suspected cases neurological syndromes, pointing to the need to increase awareness and improve training of field staff.
\end{abstract}

KEYWORDS: diagnosis; neurological syndrome; surveillance; zoonosis.
RESUMO: Bovinos e equinos são os animais domésticos com maior incidência de raiva no Brasil. Este estudo avaliou formulários de solicitação de testes para raiva em herbívoros acompanhando amostras enviadas a um laboratório certificado de diagnóstico de raiva no estado do Rio Grande do Sul, Brasil. As informações foram obtidas sistematicamente de todos os formulários enviados ao laboratório em 2013 e 2014 utilizando um instrumento de coleta que selecionou variáveis sobre o tipo de formulário utilizado, município de origem, descrição do animal suspeito, sinais clínicos, coleta de amostra e procedimento de conservação. As 11 variáveis mais relevantes (município de origem, coordenadas geográficas, espécie, gênero, raça, idade, tamanho do rebanho, sinais clínicos, persistência de sinais clínicos, material biológico e conservação da amostra) foram avaliadas quanto à qualidade dos dados inseridos, e os dados percentuais foram calculados por formulário. No total, 603 formulários foram enviados para o laboratório. O formulário mais utilizado foi o FORM SN, (82,0\%, 497/603). Dados classificados como "excelentes" e "bons" foram observados apenas para uma variável que descreve a localização de casos suspeitos de raiva ou surtos e animais (espécie, gênero, material biológico). A qualidade da entrada dos dados das variáveis que descrevem coordenadas geográficas, idade, raça, tamanho do rebanho, sinais clínicos, persistência de sinais e método de conservação da amostra variou entre "regular" e "ruim". A qualidade dos dados dos formulários de solicitação de testes para herbívoros náo foi devidamente fornecida em casos suspeitos de síndromes neurológicas, apontando para a necessidade de aumentar a conscientizaçáo e melhorar o treinamento do pessoal de campo.

PALAVRAS-CHAVE: diagnóstico; síndrome neurológica; vigilância; zoonose.

\footnotetext{
'Laboratório de Virologia, Centro de Pesquisa em Saúde Animal, Instituto de Pesquisas Veterinárias Desidério Finamor, Secretaria da Agricultura Pecuária e Desenvolvimento Rural - Eldorado do Sul (RS), Brazil

${ }^{2}$ Laboratório de Histopatologia, Centro de Pesquisa em Saúde Animal, Instituto de Pesquisas Veterinárias Desidério Finamor, Secretaria da Agricultura Pecuária e Desenvolvimento Rural - Eldorado do Sul (RS), Brazil

*Corresponding author: angelbertagnolli@gmail.com

Received on: 05/26/2018. Accepted on: 04/06/2020.
} 


\section{INTRODUCTION}

Rabies is a fatal encephalitis that affects humans and both domestic and wild animals. The disease is caused by a single-strand RNA virus of the Genus Lyssavirus, Family Rhabdoviridae (RUPPRECHT et al., 2002). In Brazil, rabies is one of the main causes of neurological syndromes in production animals like cattle and horses (RISSI et al., 2010; TEIXEIRA et al., 2015).

In the effort to control rabies in herbivores in Brazil, the country's Ministry of Agriculture, Livestock and Food Supply (Ministério da Agricultura, Pecuária e Abastecimento MAPA) implemented the National Rabies Control Program in Herbivores (Programa Nacional de Controle da Raiva dos Herbívoros - PNCRH). The aim was to develop strategies of vaccination of domestic herbivores, to improve health awareness, to define epidemiologic surveillance protocols, to notify certified veterinary health services of suspected rabies cases, and to appropriately collect, store, and ship samples of the central nervous system (CNS) for laboratory diagnosis of the disease (BRASIL, 2009; BRASIL, 2013). Samples must be collected by a veterinarian or certified personnel, kept refrigerated or frozen, and shipped to a certified laboratory. When the suspected case is that of an adult ruminant, included in the list of animals that are analyzed for Transmissible Spongiform Encephalopathies (TSE), a sample of the CNS also has to be provided, be kept refrigerated or frozen, and be subjected to the ELISA screening test (BRASIL, 2018).

In addition, all samples of suspected rabies cases have to be accompanied by a form called Unified Neurologic Syndrome Testing Request Form (FORM SN) (BRASIL, 2009). The data included in the FORM SN are very important, since they are used to prepare reports to the World Organization for Animal Health (OIE) and to devise control actions. In this scenario, the present study assessed the data input in exam request forms for neurologic syndromes shipped with material for analysis in a certified laboratory in the state of Rio Grande do Sul (RS), Brazil.

\section{MATERIAL AND METHODS}

\section{Study site, period, and population}

The rabies test request forms for herbivores analyzed were sent to the Virology Laboratory of the Veterinary Research Institute "Desidério Finamor" (Instituto de Pesquisa Veterinária Desidério Finamor - IPVDF), which is an organization within the Department of Research and Diagnosis in Agricultural and Livestock Production of the Secretariat of Agriculture, Livestock, and Irrigation of the state of Rio Grande do Sul (RS), Brazil. The records included were sent to IPVDF in
2013 and 2014 accompanying samples of tissues from animals with suspected rabies in RS only.

\section{Data collection}

Data were obtained using a collection instrument listing variables describing the kind of form used, municipality of origin, data describing the animal affected, clinical signs, sample collection, and conservation procedures. The variables included in the study were selected based on FORM SN (BRASIL, 2009) and the relevant information was transferred to a collection instrument. All filled out instruments were checked by an observer to detect and correct any mistakes. After the instruments were reviewed, all information was entered in a databank created using the software EpiData (3.0) by two trained typists. Each typist entered all data from instruments in the database, and the files obtained were compared to find and correct any mistakes based on a second inspection of the instruments.

\section{Data analysis}

The databank containing all information was exported to a Microsoft Office Excel ${ }^{\circ} 2010$ spreadsheet. The absolute and percent frequency values on the forms were calculated for each variable. The results were classified into five categories according to a scoring system adapted from a previous study (ROMERO et al., 2007). This scoring system considers data input as "excellent" when over $95 \%$ of the data requested on a form are provided. The scores "good", "average", "poor", and "very poor" are given when $90.0-95.0 \%, 80.0-90.0 \%$, $50.0-80 \%$, and less than $50.0 \%$ of the required data are given in forms, respectively. Variation was calculated using Equation and percent values of variables.

\section{RESULTS}

In total, 603 forms were reviewed, of which 287 were submitted in 2013 and 316 in 2014. FORM SN was used in 82\% (487/603) of the forms. But in addition to FORM SN, other forms were also submitted to IPVDF, such as the Disease Investigation Form - Screening (FORM IN), the Disease Investigation Form - Complementary (FORM COM), the test request form used by IPVDF, the form prescribed by the Health Bureau of $\mathrm{RS}$, and forms issued by the entity requesting testing. Table 1 presents the types and percentage values of each form sent to IPVDF during the two-year period.

The percentage data input values and the classification of the 11 variables analyzed (municipality of origin, geographic coordinates, species, gender, breed, age, herd size, clinical signs, persistence of clinical signs, biological material, and sample conservation) are shown in Table 2. 
Municipality of origin, species, and biological material were the only variables with excellent percentage data input values. The variable gender presented good percentage data input values, at $91 \%(547 / 603)$. The other variables had average or poor data input values (Table 2).

Clinical signs were supplied in $78 \%(468 / 603)$ of the forms. In 2013, the most frequent clinical signs were depression and lack of coordination. In 2014, the most common sign was a lack of coordination. The section for sample conservation was filled out in $67 \%$ (404/603) of the forms.

Also, $41 \%(245 / 603)$ of the samples were from bovines aged over 24 months and small ruminants over 12 months old. Of that number, only $4 \%(9 / 245)$ were either kept frozen, refrigerated, or in formalin.

The annual variation in percentage data input values was calculated using Equation 1. The comparison of results between 2014 and 2013 showed that percentage data input decreased only for clinical signs, herd size, and breed, which was supplied in 21,4 , and $9 \%$ fewer forms. The fields for the other variables were filled out in the same or in a higher number of forms.

Table 1. Summary of forms and rabies test request forms.

\begin{tabular}{lcc|}
\hline Form type & Absolute number & Percentage \\
\hline FORM SN* & 333 & 55 \\
\hline FORM SN + FORM IN** & 108 & 18 \\
\hline FORM SN + others*** & 56 & 9 \\
\hline FORM IN & 42 & 7 \\
\hline Only others & 64 & 11 \\
\hline Total number of forms & 603 & 100 \\
\hline
\end{tabular}

*Unified Neurologic Syndrome Testing Request Form; **Disease Investigation Form - Screening; ${ }^{* * *}$ Others include Disease Investigation Form - Complementary (FORM COM), the test request form used by IPVDF and forms issued by the entity requesting testing.

\section{DISCUSSION}

In Brazil, MAPA and PNCRH require that all samples shipped for diagnosis should be accompanied by FORM SN (BRASIL, 2009). The present study showed that $18 \%$ of material shipped for rabies testing did not include that form. These samples were accompanied by other forms, such as FORM IN (which records the first visit of a certified veterinarian in a farm where an outbreak or a suspected case occurs and proceeds with the compulsory official notification procedure) and FORM COM (used by a certified veterinarian in subsequent visits to investigate outbreaks or suspected cases), in addition to the form used by IPVDF. These forms are useful as complementary sources of information for the data in FORM SN, but they do not provide much insight into the diagnosis of rabies when they are the only forms used.

An essential section in FORM SN describes the location of the property where an animal suspected of rabies lives. According to PNCRH, data about geographical coordinates should be supplied to three figures for degree, two for minute, two for second, and one for tenth of second based on the geodesic system. Moreover, it is important to clarify the mathematical sign of coordinates, which are positive for hemispheres north and east and negative for south and west of the Equator and the Greenwich meridian. These measures ensure the accurate location of the farm where suspected cases of rabies are being investigated. In the present study, the geographical coordinates were not adequately provided in more than $30 \%$ of the forms, in which latitude and longitude were not given to the required number of figures. These forms were classified as having a low percentage of data input. In a study carried out in the State of Pará, Brazil, georeferencing helped to detect areas of high risk of rabies transmission by the hematophagous bat species Desmodus rotundus to both humans and

Table 2. Percent data input of variables as supplied in rabies testing request form.

\begin{tabular}{|c|c|c|c|c|c|c|c|}
\hline \multirow[b]{2}{*}{ Variable } & \multicolumn{3}{|c|}{2013} & \multicolumn{3}{|c|}{2014} & \multirow{2}{*}{$\begin{array}{c}\text { Variation } \\
\text { (\%) }\end{array}$} \\
\hline & $\begin{array}{l}\text { Completed } \\
\text { forms (n) }\end{array}$ & $\begin{array}{l}\text { Completed } \\
\text { forms (n\%) }\end{array}$ & Score & $\begin{array}{l}\text { Completed } \\
\text { forms (n) }\end{array}$ & $\begin{array}{l}\text { Completed } \\
\text { forms (n\%) }\end{array}$ & Score & \\
\hline Municipality of origin & 287 & 100 & Excellent & 316 & 100 & Excellent & 0 \\
\hline Geographic coordinates & 171 & 60 & Poor & 240 & 76 & Poor & 27 \\
\hline Species & 287 & 100 & Excellent & 316 & 100 & Excellent & 0 \\
\hline Gender & 260 & 91 & Good & 287 & 91 & Good & 0 \\
\hline Breed & 196 & 68 & Poor & 196 & 62 & Poor & 9 \\
\hline Age & 248 & 86 & Average & 277 & 88 & Average & 2 \\
\hline Herd size & 223 & 78 & Poor & 238 & 75 & Poor & 4 \\
\hline Clinical signs & 249 & 87 & Average & 219 & 69 & Poor & 21 \\
\hline Persistence of clinical signs & 177 & 62 & Poor & 240 & 76 & Poor & 23 \\
\hline Biological material & 279 & 97 & Excellent & 309 & 98 & Excellent & 1 \\
\hline Sample conservation & 169 & 59 & Poor & 235 & 74 & Poor & 25 \\
\hline
\end{tabular}


bovines (ANDRADE et al., 2016). The system also made it possible to characterize these areas. Research in the state of Minas Gerais, Brazil, showed that georeferencing detected the expansion of risk areas and indicated a decrease in passive surveillance of rabies in the region (OVIEDO-PASTRANA et al., 2015). These studies underscore the importance of identifying the geographical origin of rabies cases, producing data that may be suitable in the development of epidemiological models used in strategies to improve the surveillance, control, and prevention of rabies. However, the poor data input about the geographical coordinates of rabies cases in RS, as revealed in the present study, is an obstacle in the identification of high risk areas in the state and in the development of such strategies.

Data about the species of animals suspected of rabies are important in the identification of populations at risk and in characterizing prophylaxis. The results of the present study show that species and gender were supplied in almost all forms, though age was not provided in 14 and $12 \%$ of forms in 2013 and 2014, respectively. The poor information about age is a problem in the surveillance of the TSE investigated by the PNCRH. Clear age identification is essential to identify target populations, because the atypical manifestation of TSE may affect older animals (LAURINDO; BARROS FILHO, 2017). According to the Brazilian regulation, all biological material that is negative for rabies collected from bovines and small ruminants over 24 and 12 months of age, respectively, should be tested for TSE (BRASIL, 2002).

The description of clinical signs is important to characterize the health status of animals suspected of rabies and to establish the differential diagnosis of the disease. In the present study, despite the fact that most forms used were FORM SN, which includes fields to provide the clinical signs observed,
$13 \%$ of forms contained no information about the manifestations of rabies that animals may have shown.

Sample conservation was the variable correctly provided in the least number of forms. The version of the FORM SN used includes a field to be filled out on the method of sample conservation. Yet, in some forms, the information given was about the method of transportation of samples rather than conservation.

During the study period, the PNCEBT stipulated that samples shoulded also be provided preserved in formalin $10 \%$. This is due to the need to carry out histological evaluations of TSE and to differentially diagnose other diseases, if the results for rabies are negative (BARROS; MARQUES, 2003). It should be highlighted that $96 \%$ of the samples obtained from adult ruminants were sent refrigerated, which does not meet the requirements established by the TSE surveillance system in Brazil. Similar results were obtained in a study that evaluated samples sent to another laboratory that diagnoses rabies in the country (OLIVEIRA et al., 2012).

\section{CONCLUSIONS}

The evaluation of percentage data input in forms to request rabies tests showed that the only variables correctly provided were municipality of origin, species, and biological material. In addition, a number of samples were not sent accompanied by the FORM SN, which is the standard form required by PNCRH. The results highlight the need to train field staff to appropriately fill out forms and follow existing rules to submit samples for the diagnosis of rabies.

ACKNOWLEDGMENTS: The authors gratefully acknowledge the Brazilian research funding agencies: National Council for Scientific and Technological Development (CNPq) and the Rio Grande do Sul State Research Foundation (FAPERGS) by their concession of the Scientific Initiation Scholarship.

FUNDING: This study was funded by Financiadora de Estudos e Projetos (FINEP/SANIMARS) - Grant number 01 100783-00). CONFLICTS OF INTEREST: All authors declare that they have no conflict of interest.

ETHICAL APPROVAL: Not applicable.

AVAILABILITY OF DATA AND MATERIAL: All data generated or analyzed during this study are included in this published article.

AUTHORS' CONTRIBUTIONS: Conceptualization: Bertagnolli; A.C.; Lopes, L.L.A. Data curation: Migliavacca, V.F.; Peres, M. E. Formal analysis: Ferreira, J.C.; Rosa, J.C.A.; Braga, A.C. Methology: Bertagnolli; A.C.; Lopes, L.L.A. Writing- review \& editing: Migliavacca, V.F.; Dantas, G.D; Bertagnolli, A.C.; Lopes, L.A. 


\section{REFERENCES}

ANDRADE, F.A.; GOMES, M.N.; UIEDA, W.; BEGOT, A.L.; RAMOS, O.D.E.S.; FERNANDES, M.E. Geographical analysis for detecting high-risk areas for bovine/human rabies transmitted by the common hematophagous bat in the Amazon Region, Brazil. PLOS One, São Francisco, v.1 1, n.7, p.e0157332.B, 2016. https:// doi.org/10.1371/journal.pone.0157332

BARROS, C.S.L.; MARQUES, G.H.F. Procedimentos para o diagnóstico das doenças do sistema nervoso central de bovinos. Brasília, DF: Secretaria de Defesa Agropecuária, Departamento de Defesa Animal, 2003.

BRASIL. Instrução Normativa n 18, de 15 de fevereiro de 2002. Aprova as Normas a serem adotadas, visando incrementar a vigilância epidemiológica para detecção de Encefalopatias Espongiformes Transmissíveis -EET - em ruminantes. Diário Oficial da União, Brasília, 2002. Available from: https://www.jusbrasil. com.br/diarios/458789/pg-1-secao-1-diario-oficial-da-uniaodou-de-19-02-2002. Access on: Apr 20, 2018.

BRASIL. Ministério da Agricultura, Pecuária e Abastecimento (MAPA). Secretaria de Defesa Agropecuária. Controle da raiva dos Herbívoros - Manual Técnico, Brasília, DF, 2009. 124p. Available from: http://www.agricultura.gov.br/assuntos/sanidade-animale-vegetal/saude-animal/programas-de-saude-animal/raivados-herbivoros-e-eeb/MANUAL_RAIVAHERBVOROS2009.pdf. Access on: Mar 15, 2018.

BRASIL. Instrução Normativa n 50, de 24 de setembro de 2013 Lista de Doenças de Notificação Obrigatória Ao Serviço Veterinário Oficial. Diário oficial da União, Brasília, 2013. Available from https://www.jusbrasil.com.br/diarios/59516948/dou-secao1-25-09-2013-pg-47. Access on: Mar 15, 2018.

BRASIL. Memorando-Circular n 57/2018/DSA/SDA/MAPA, de 26 de outubro de 2018 , que informa sobre a alteração da conservação de amostras de campo para vigilância das encefalopatias em atenção ao Memorando no 1072/2018/ DLAB-PE/LANAGRO-PE/CGAL/MAPA/SDA/MAPA. Available from: http://portal.cfmv.gov.br/noticia/index/id/5895/ secao/6/\#memo. Access on: Apr 02, 2020.
LAURINDO, E.E.; BARROS FILHO, I.R.B. Encefalopatia espongiforme bovina atípica: uma revisão. Arquivos do Instituto Biológico, São Paulo, v.84, p.1-10, 2017. https://doi. org/10.1590/1808-1657000392015

OLIVEIRA, T.S.; BULL, V.; REZENDE, C.A.; FURTINI, R.; COSTAS, E.A.; PAIXÃO, T.A.; SANTOS, R.L. Perfil das amostras do sistema nervoso central de bovinos com síndrome neurológica e diagnóstico da raiva bovina no serviço de defesa sanitária de Minas Gerais, 2003-2010. Pesquisa Veterinária Brasileira, Rio de Janeiro, v,32, n.4, p.333-339, 2012. https://doi.org/10.1590/ so $100-736 \times 2012000400010$

OVIEDO-PASTRANA ME, OLIVEIRA CSF, CAPANEMA RO, NICOLINO RR, OVIEDO-SOCARRAS TJ.; HADDAD, J.P.A. Trends in animal rabies surveillance in the endemic State of Minas Gerais, Brazil. PLOS Neglected Tropical Diseases, São Francisco, v.9, n.3, p. e0003591, 2015. https://doi.org/10.1371/journal.pntd.0003591

RISSI, D.R.; PIEREZAN, F.; OLIVEIRA-FILHO, J.C.; LUCENA, R.B.; CARMO, P.M.S.; BARROS, C.S.L. Abordagem diagnóstica das principais doenças do sistema nervoso de ruminantes e equinos no Brasil. Pesquisa Veterinária Brasileira, Rio de Janeiro, v.30, n. 11 , p.958-967, 2010. https://doi.org/10.1590/ So $100-736 \times 2010001100010$

ROMERO, D.E.; CUNHA, C.B. Avaliação da qualidade das variáveis epidemiológicas e demográficas do Sistema de Informações Sobre Nascidos Vivos, 2002. Cadernos de Saúde Pública, Rio de Janeiro, v.23, n.3, p.701-714, 2007. https://doi.org/10.1590/ So $102-311 \times 2007000300028$

RUPPRECHT, C.E.; HANLON, C.A.; HEMACHUDHA, T. Rabies re-examined. Lancet Infectious Diseases, London, v.2, n.6, p.327343, 2002. https://doi.org/10.1016/s1473-3099(02)00287-6

TEIXEIRA, L.H.M.; TOMAZ, L.A.G.; LINHARES, G.F.C.; SANTOS, M.F.C.; JAYME, V.S. Distribuição espaço-temporal dos diagnósticos laboratoriais da raiva animal. Ciência Animal Brasileira, Goiânia, v.16, n.1, p.144-157, 2015. https://doi. org/10.1590/1809-6891v16i131282 